would take some $60 \%$ of the NSF allocation, research funding will almost double in the coming year. This effort will focus on the design, planning, construction and use of various manmade works to resist earthquakes. Another $20 \%$ of NSF funds would probably go to related socio-economic and policy areas.

On the same basis, USGS is likely to devote about half its allocation to the development of methods to predict the time, place and magnitude of future earthquakes. Another 35\% or so would go on assessing earthquake hazards, while a small amount would be spent on studies of artificial earthquake inducement.

As for fiscal years 1979 and 1980 , the 50:50 split between the two agencies would continue for budgets totalling $\$ 70$ million and $\$ 80$ million; the breakdown could be expected to follow broadly the same pattern. If the patterns of spending are predictable, however, the scientific results are not. Recent scientific progress in the field has probably assisted the bill's passage; reliable earthquake prediction seems more likely than ever before.

Of equal importance for the bill, however--apart from an unsubstantiated sense that more earthquakes than usual have struck in recent yearswas the support given by the Carter Administration, notably by the Office of Science and Technology Policy in the White House, which is headed by the President's science adviser, Frank Press, himself a geophysicist. Indeed, the bill reflects many of the Administration's preferences. When it came out of the House Interior and Insular Affairs Committee, under which USGS falls, the important difference from the bill it received from the House Science and Technology Committee, and which put it in line with the Senate version, was that it contained no specific institutional proposals. The bill it received had suggested an Office of Earthquakes Hazards Reduction, a National Advisory Committee, and an Earthquake Prediction Evaluation Board.

Given the President's desire for flexibility while pursuing plans for government re-organisation, these suggestions were premature. Accommodatingly, the bill thus provides simply for designation of a "lead agency", and the usual establishment by the President of roles and goals.

On Capitol Hill not all reactions

Colin Norman leaves Nature this week to go to the Worldwatch Institute in Washington. He has been our Washington correspondent for about six years, having previously worked in the London office. With his departure the journal loses a distinguished observer of the scientific scene.

\title{
Controlling technology flow
}

QUESTION: how does a technologically and militarily sophisticated superpower, which is committed to free trade principles, contain the contribution that its much sought-after exports might make to the military capability of potential adversaries? Answer: it's a problem. The latest round in a recurring debate in the United States on the matter came immediately before the Labor Day weekend at the end of August, when the Secretary for Defense, Harold Brown suddenly released a five-page memorandum sent to various officials in defence-related agencies.

Cast as an interim policy statement on controls over the export of US technology, the memorandum draws on the recommendations from the Defense Science Board Task Force, published last year as the so-called Bucy Report (see Nature, 15 April 1976. This indicated that controls over the flow of strategic or "critical" technology to Communist countries had broken down in recent years, and suggested that the United States should refine the list of relevant technologies and apply sanctions where they were unwarrantedly passed on, directly or otherwise.

The "interim internal guidance" which the Brown memorandum provides for the Department of Defense (DOD) covers exports both to allies and to potential adversaries. It says DOD will support the transfer of critical technology to countries with which the US has a major security interest where this can strengthen collective security, contribute to NATO standardisation and enhance the return on R\&D. But with both allies and other non-Communist countries, DOD will also assess the recipient's "intent and ability to prevent either the compromise or the unauthorised re-export of that technology", relying on the intelligence and security communities to help discover any breaches. Violations would result in sanctions.

Regarding exports to potential adversaries, a "presumption for recommending disapproval" will operate where these involve a revolutionary advance in defence-related technology. But where they involve end products not of strategic importance or with virtually unextractable valuable technology, DOD will normally recommend approval. Either way, the key consideration would be the recipient's military capability.

According to the memorandum, the Department of Defense will be asking the Commerce Department to change present regulations so that exports of critical technology to all countries would require a valid licence; DOD will also recommend a streamlining of application procedures to minimise delays. In addition, DOD will suggest that the State Department negotiate new measures to control the flow of technology to Communist countries with the Consultative Group Coordinating Committee (COCOM), which is a group of NATO countries and Japan.

The primary objective in all this, of course, is to protect US lead times in the application of technology to military capabilities. The hope is that this will be more readily achieved through an emphasis on technology rather than end products, and by having the policy cover all countries using faster procedures. The provision allowing for DOD "recommendation" will help here; so too will the plan to maintain a continuously updated list of critical technologies. No indication was available, however, regarding the timetable for a fully national policy; that will bring in other government departments.

In the meantime, one minor worry remains. A covering letter to the Bucy Report described, as potentially an "area of concern", the scientific exchange agreements under which scientists move between the USA and the Soviet Union. The Brown memorandum does not take this matter up in any real detail, but says that when the potential for "inadvertent transfer" is high, DOD will recommend restrictions "on the amount, extent or kind of interpersonal exchange". Such exchanges are already subject to certain procedures and regulations, however, and the Head of the Exchanges Office at the State Department says the memorandum implies no changes.

Chris Sherwell were positive. Senator Alan Cranston of California, who has sought earthquake legislation for five years, naturally welcomed passage of the bill as a "historic step"; last year he saw his own bill, already passed by the Senate, die in the House at the end of the session. But in the House a Maryland Republican was more caustic: a Congress which could not detect an inflationary impact in spending a quarter of a billion dollars, he suggested, "could not possibly detect an earthquake". 